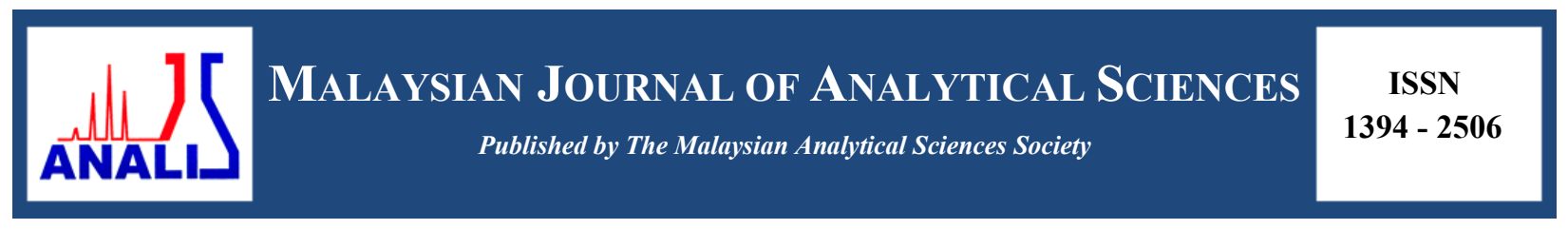

\title{
ANALYSIS OF AMMONIUM ADSORPTION BEHAVIOR AND MASS TRANSFER RESISTANCE FROM AERATED LAGOON EFFLUENT ONTO ACTIVATED CARBON
}

\author{
(Analisis Sifat Penjerapan Amonium dan Rintangan Pemindahan Jisim dari Efluen Kolam \\ Pengudaraan Terhadap Karbon Teraktif) \\ Mohd Hairul Khamidun ${ }^{1}$, Shakila Abdullah ${ }^{2}$, Umi Fazara Md.Ali ${ }^{3}$, Mohamad Ali Fulazzaky ${ }^{4}$ \\ ${ }^{I}$ Micropollutant Research Centre, Faculty of Civil and Environmental Engineering \\ ${ }^{2}$ Faculty of Science, Technology and Human Development \\ Universiti Tun Hussein Onn Malaysia, 86400 Parit Raja, Batu Pahat, Malaysia \\ ${ }^{3}$ School of Environmental Engineering, \\ Universiti Malaysia Perlis, Kompleks Pusat Pengajian Jejawi 3, 02600 Arau, Perlis, Malaysia \\ ${ }^{4}$ Directorate General of Water Resources, \\ Ministry of Public Works and Housing, Jakarta, Indonesia \\ *Corresponding author: mhairulk@gmail.com
}

Received: 16 April 2017; Accepted: 7 March 2018

\begin{abstract}
High concentration ammonium $\left(\mathrm{NH}_{4}^{+}\right)$discharges from aerated lagoon effluent (ALE) correlated to eutrophication of receiving waters. This study presents the first attempt to scrutinise the mass transfer mechanism of $\mathrm{NH}_{4}^{+}$from ALE onto the granular activated carbon (GAC) in batch and plug-flow column (PFC) studies. The GAC was characterised by BET surface, X-ray fluorescence, scanning electron microscopy, X-ray diffraction and Fourier transform infrared spectroscopy. The kinetics and isotherm models were applied to experimental data to understand adsorption behaviour, while mass transfer factor (MTF) models was used to determine global, external, and internal mass transfer. The PFC was successfully applied for the removal of $\mathrm{NH}_{4}^{+}$ from ALE. The results showed that the adsorption of $\mathrm{NH}_{4}{ }^{+}$from ALE on the GAC followed the pseudo-second-order kinetic model and the Freundlich adsorption isotherm in batch study. The resistances of mass transfer for adsorption of $\mathrm{NH}_{4}{ }^{+}$onto $\mathrm{GAC}$ from the PFC are verified. The use of these empirical models has been proved that the models were very suitable for PFC design and understanding mechanism of mass transfer of solutes from waters onto porous materials.
\end{abstract}

Keywords: adsorption, ammonium, isotherm, kinetics, mass transfer resistance

Abstrak

Kepekatan amonium $\left(\mathrm{NH}_{4}^{+}\right)$yang tinggi di dalam efluen yang dilepaskan dari kolam pengudaraan (ALE) akan menyebabkan eutrofikasi pada saliran yang menerima efluen tersebut. Kajian ini dijalankan untuk meneliti mekanisma rintangan permindahan jisim $\mathrm{NH}_{4}^{+}$dari ALE ke seluruh karbon teraktif berbutir (GAC) menggunakan kaedah ujikaji berkelompok dan aliran penuh ruangan berongga (PFC). Sifat fizikal dan kimia GAC ditentukan dengan menggunakan ujikaji permukaan BET, pendarfluor sinar-X, mikroskopi elektron pengimbasan, pembelauan sinar-X dan spektroskopi inframerah transformasi Fourier. Sifat penjerapan GAC telah dianalisis dengan menggunakan model isoterma dan kinetik, manakala model faktor permindahan jisim (MTF) digunakan untuk menganalisis faktor permindahan jisim global, luaran dan dalaman. Penggunaan PFC telah diuji dan disahkan berkesan untuk menyingkirkan $\mathrm{NH}_{4}^{+}$dari ALE. Hasil ujikaji berkelompok menunjukkan penjerapan $\mathrm{NH}_{4}{ }^{+}$dari ALE telah mematuhi prinsip model kinetik tertib kedua dan model penjerapan isorterma Freundlich. Rintangan permindahan jisim untuk penjerapan $\mathrm{NH}_{4}^{+}$ke seluruh GAC dari PFC telah disahihkan. Penggunaan semua model yang dinyatakan telah 
membuktikan bahawa model tersebut sesuai digunakan untuk rekabentuk PFC dan juga untuk memahami mekanisma permindahan bahan terlarut dalam air ke seluruh bahan berliang.

Kata kunci: penjerapan, amonium, isorterma, kinetik, rintangan permindahan jisim

\section{Introduction}

Activated carbon (AC) is a material that has a porosity characterised by empty space within pore. Activation of AC increases the porosity and active sites on its surface to increase the adsorption capacity. The use of certain type of $\mathrm{AC}$ could be useful for the remove of ammonium $\left(\mathrm{NH}_{4}{ }^{+}\right)$from aqueous solutions. High amount of $\mathrm{NH}_{4}{ }^{+}$present in aerated lagoon effluent can cause adverse effects on the environment when released into water body. An increase in $\mathrm{NH}_{4}{ }^{+}$concentration released into the water bodies can cause the eutrophication. Note that eutrophication is an excess nutrient load of any waters, which is reflected by rapid growth of blue green algae. According to Fan et.al. [1], $\mathrm{NH}_{4}{ }^{+}$is the primary nitrogen sources that cause the Choptank River bloom and the ambient uptake rates of $\mathrm{NH}^{4+}$ directly proportional with algae bloom progressed in Choptank River. Therefore, the algae bloom can be controlled by reducing the concentration of $\mathrm{NH}_{4}{ }^{+}$in wastewater during the treatment process before discharging into water bodies.

The adsorption of $\mathrm{NH}_{4}{ }^{+}$from leachate by the $\mathrm{AC}$ made up of coconut shells as reported by Halim et al. [2] can achieve approximately $6.08 \mathrm{mg} \mathrm{g}^{-1}$ of the adsorption capacity. The adsorption capacity of $2.30 \mathrm{mg} \mathrm{g}^{-1}$ to remove $\mathrm{NH}_{4}^{+}$from aqueous solution was verified by Boopathy et al. [3] in a batch experiment; therefore, physisorption could be more dominant. Many researchers have been focusing their investigations on physical or chemical properties of AC in order to improve the adsorption capacity [4-7]. Vassileva et al. [8] found that the coal activated carbon modified by nitric acid can significantly enhance the $\mathrm{NH}_{4}{ }^{+}$removal from aqueous solutions. A mixture adsorbent of $45.94 \%$ zeolite, $15.31 \%$ limestone, $4.38 \%$ activated carbon and $4.38 \%$ rice husk carbon was used to adsorb $\mathrm{NH}_{4}{ }^{+}$from a landfill leachate and verified that a high adsorption capacity can achieve approximately 24.39 $\mathrm{mg} \mathrm{g}^{-1}$ of the adsorbent [9]. Even though many studies have been conducted to verify the efficiency of granular activated carbon (GAC) to remove $\mathrm{NH}_{4}{ }^{+}$from aqueous solutions, the mechanism of mass transfer for the adsorption of $\mathrm{NH}_{4}{ }^{+}$onto GAC from ALE is still not fully understood.

The mechanisms of adsorption consist of three successive steps in the transfer of solutes onto adsorbents in liquid, such that: (1) film mass transfer (referred also as external mass transfer) is the mechanism to transport an adsorbate from the bulk liquid to film zone exterior the grain immediately connecting the pores, (2) porous diffusion (referred also as internal mass transfer) is mechanism to diffuse an adsorbate from the film zone towards acceptor sites of the adsorbent, and (3) fixation (referred also as adsorption) is mechanism to attach the adsorbate onto acceptor sites of the adsorbent interior the grain [10,11]. In spite of reducing the concentration of $\mathrm{NH}_{4}^{+}$can be achieved through adsorption process, the resistance of mass transfer of the adsorption in a plug-flow column needs to be verified. Therefore, the objectives of this study are to (i) to determine the kinetic and isotherm adsorption for the adsorption of $\mathrm{NH}_{4}{ }^{+}$onto GAC based on the data of batch experiments and (ii) to analysis the variation of $\left[k_{\mathrm{L}} a\right]_{\mathrm{g}},\left[k_{\mathrm{L}} a\right]_{\mathrm{f}}$ and $\left[k_{\mathrm{L}} a\right]_{\mathrm{d}}$ for adsorption of $\mathrm{NH}_{4}{ }^{+}$from ALE onto GAC in a PFC by using MTF models.

\section{Characteristics of aerated lagoon effluent}

\section{Materials and Methods}

This study monitored some important parameters of water quality over a period of 6 months for characterisation of the ALE. The average concentrations of $\mathrm{NH}_{4}{ }^{+}, \mathrm{PO}_{4}{ }^{3-}, \mathrm{COD}$ and $\mathrm{SS}$ were verified as high as 13.4, 9.5, 192 and 89 $\mathrm{mg} \mathrm{L}{ }^{-1}$, respectively. The concentration of $\mathrm{NH}_{4}{ }^{+}$was found to exceed highly above the admissible limits of the EU and USEPA effluent standards.

\section{Adsorbent}

The GAC made up of coconut shell was purchased from the Nikom Carbon Technology Sdn. Bhd. Klang, Selangor, Malaysia. Main characteristics of the GAC as provided by the supplier are listed in Table 1. The GAC was crushed and passed through a $2.13 \mathrm{~mm}$ mesh sieve and retained on $1.18 \mathrm{~mm}$ mesh sieve. Approximately $2 \mathrm{~kg}$ of the GAC was washed with distilled water and dried at $103{ }^{\circ} \mathrm{C}$ for 24 hours in an oven. The dried GAC used as adsorbent for the adsorption of $\mathrm{NH}_{4}{ }^{+}$from ALE in batch and plug-flow column. 
Table 1. Main characteristics of the granular activated carbon

\begin{tabular}{lcc}
\hline Characteristic & Unit & Value \\
\hline Origin (raw material) & & Coconut shell \\
Bulk density & $\mathrm{g} \mathrm{cm}^{-3}$ & 0.49 \\
Moisture contents & $\%$ & 2.96 \\
Hardness & $\%$ & 98.17 \\
Ash content & $\%$ & 2.32 \\
Mesh size 8 x 30 & $\%$ & 96.17 \\
BET surface area & $\mathrm{m}^{2} \mathrm{~g}^{-1}$ & 1076 \\
pH & & 9.89 \\
\hline
\end{tabular}

\section{Instruments}

The mineralogy of the GAC was identified by XRD pattern using Bruker D8 Advance X-ray powder Diffractometer (Bruker AXS, Germany). Fourier transform infrared (FTIR) analysis was performed on $\mathrm{KBr}$ pellets using a Spectrum One FT-IR Spectrometer (Perkin Elmer Instruments, USA) in the wavenumber range between 600 and $4000 \mathrm{~cm}^{-1}$. Surface morphologies of GAC were observed by a scanning electron microscopy (SEM) using a JSM638OLA instrument (JEOL Co., Ltd., Japan). The surface area of the GAC is determined by the Brunauer Emmet Teller (BET) method using a PulseChemiSorb 2705 apparatus (Micromeritics Instrument Co., USA).

The surface functional groups of GAC were identified using the Boehm titration method, where $2 \mathrm{~g}$ of GAC was placed in contact with $250 \mathrm{~mL}$ of $\mathrm{NaOH}, \mathrm{Na}_{2} \mathrm{CO}_{3}, \mathrm{NaHCO}_{3}$ or $\mathrm{HCl}$ solution with a concentration of $0.1 \mathrm{~mol} \mathrm{~L}^{-1}$ in an Erlenmeyer flask, separately. All the sample solutions in Erlenmeyer flask and their related blanks without filled with GAC in Erlenmeyer flask were sealed and shaken in an IKA KS 4000 I Control shaker for 24 hours at 225 rpm. Then, an aliquot of $10 \mathrm{~mL}$ was filtered and the excess of bases or acid was titrated with a $0.1 \mathrm{~mol} \mathrm{~L}^{-1}$ of $\mathrm{HCl}$ solution or a $0.1 \mathrm{~mol} \mathrm{~L}^{-1}$ of $\mathrm{NaOH}$ solution, respectively. The number of acidic sites was determined under the assumptions that $\mathrm{NaOH}$ neutralised carboxylic groups $(-\mathrm{COOH})$, lactonic $(\mathrm{C}=\mathrm{O})$ and phenolic $(-\mathrm{OH}) ; \mathrm{Na}_{2} \mathrm{CO}_{3}$ neutralised carboxyl groups and lactones, and $\mathrm{NaHCO}_{3}$ neutralised carboxyl groups only. The number of basic sites was calculated based on the amount of $\mathrm{HCl}$ that reacted with the adsorbent [12]

\section{Kinetics and isotherm studies}

The batch experiments were conducted to determine adsorption isotherm and kinetic. The experiments of kinetic adsorption were conducted by adding 2, 6 and $10 \mathrm{~g}$ of the adsorbents into an Erlenmeyer flask of $250 \mathrm{~mL}$. Each Erlenmeyer flask containing of $200 \mathrm{~mL}$ of ALE was shaken at $150 \mathrm{rpm}$. Then the concentration of $\mathrm{NH}_{4}{ }^{+}$in each sample solution was monitored at appropriate time intervals until the adsorbent saturates. The pseudo-first-order and pseudo-second-order models were used to study the kinetics of the adsorption of $\mathrm{NH}_{4}{ }^{+}$onto GAC from ALE.

The pseudo-first-order equation (or so called Lagergren equation) indeed is in line with the concept of linear driving force and is commonly expressed as equation 1 below [13]:

$$
\frac{d q}{d t}=k_{1}\left(q_{e}-q_{t}\right)
$$

where $q$ is the adsorption capacity (in $\mathrm{mg} \mathrm{g}^{-1}$ ), $t$ is the adsorption time (in $\mathrm{min}$ ), $k_{1}$ is a pseudo-first-order constant (in $\left.\min ^{-1}\right), q_{\mathrm{e}}$ is the equilibrium amount of adsorbate adsorbed by per unit mass of adsorbent (in $\mathrm{mg} \mathrm{g}^{-1}$ ) and $q_{\mathrm{t}}$ is the amount of adsorbate adsorbed at adsorption time $t$ (in $\mathrm{mg} \mathrm{g}^{-1}$ ). Integrating equation (1) with boundary values from $t$ $=0$ to $t=t$ and from $q_{\mathrm{t}}=0$ to $q_{\mathrm{t}}=q_{\mathrm{t}}$ yields (equation 2):

$$
q_{t}=q_{e}\left(1-e^{-k_{1} t}\right)
$$


The first-order rate equation its liner form can be expressed as equation 3 [14]:

$$
\ln \left(q_{\mathrm{e}}-q_{\mathrm{t}}\right)=\ln \left(q_{e}\right)-k_{1} t_{\mathrm{i}}
$$

where $q_{\mathrm{e}}$ is the equilibrium amount of adsorbate adsorbed by per unit mass of adsorbent (in $\mathrm{mg} \mathrm{g}^{-1}$ ) and $q_{\mathrm{t}}$ is the amount of adsorbate adsorbed at adsorption time $t$ (in $\left.\mathrm{mg} \mathrm{g}^{-1}\right), k_{1}$ is a pseudo-first-order constant (in $\min ^{-1}$ ) and $t_{\mathrm{i}}$ is the predetermined interval time $(\mathrm{min})$.

Another model for the analysis of adsorption kinetics is pseudo-second-order (equation 4):

$$
\frac{d q}{d t}=k_{2}\left(q_{e}-q_{t}\right)^{2}
$$

where $q$ is the adsorption capacity (in $\mathrm{mg} \mathrm{g}^{-1}$ ), $t$ is the adsorption time (in min), $k_{2}$ is a pseudo-second-order constant (in $\left.\min ^{-1}\right), q_{\mathrm{e}}$ is the equilibrium amount of adsorbate adsorbed by per unit mass of adsorbent (in $\mathrm{mg} \mathrm{g}^{-1}$ ) and $q_{\mathrm{t}}$ is the amount of adsorbate adsorbed at adsorption time $t$ (in $\mathrm{mg} \mathrm{g}^{-1}$ ). Integrating equation (4) is given as

$$
q_{t}=\frac{q_{e}^{2} k_{2} t}{1+q_{e} k_{2} t}
$$

The application of pseudo-second-order model is suitable for the analysis of adsorption kinetics if the initial concentration of adsorbate is low. The second-order rate equation can be expressed in the linear form [15]:

$$
\frac{t_{\mathrm{i}}}{q_{\mathrm{t}}}=\frac{1}{k_{2} q_{\mathrm{e}}^{2}}+\frac{t_{\mathrm{i}}}{q_{\mathrm{e}}}
$$

where $t_{\mathrm{i}}$ is the predetermined interval time ( $\left.\mathrm{min}\right), q_{\mathrm{t}}$ is the amount of adsorbate adsorbed at adsorption time $t$ (in $\mathrm{mg}$ $\left.\mathrm{g}^{-1}\right), k_{2}$ is a pseudo-second-order constant (in $\min ^{-1}$ ) and $q_{\mathrm{e}}$ is the equilibrium amount of adsorbate adsorbed by per unit mass of adsorbent (in $\mathrm{mg} \mathrm{g}^{-1}$ ).

An appropriate kinetic model for the adsorption of $\mathrm{NH}_{4}{ }^{+}$onto GAC to select either pseudo-first-order or pseudosecond-order, the error function $\left(F_{\mathrm{e}}\right)$ tests were performed using the values of $q$ obtained from a batch experiment and those obtained from the calculation of using pseudo-first-order and pseudo-second-order models. The most appropriate model should have a smallest $F_{\mathrm{e}}$ value and highest correlation coefficient $\left(R^{2}\right)$. The following equation can be used to calculate value of $F_{\mathrm{e}}[16]$ :

$$
F_{e}=\sqrt{\left(\frac{1}{n-p}\right) \cdot \sum_{i}^{n}\left(q_{t(\exp )}-q_{t(\text { theo })}\right)^{2}}
$$

where $n$ is the number of measurements, $p$ is the number of parameters in the kinetic equation, $q_{\mathrm{t}(\exp )}$ is the experimental $q$ value obtained from the measurement during the experiments (in $\mathrm{mg} \mathrm{g}^{-1}$ ) and $q_{\mathrm{t} \text { (theo) }}$ is the theoretical $q$ value calculated by the model (in $\mathrm{mg} \mathrm{g}^{-1}$ ).

The isotherm experiments were carried out by adding 2, 4, 6, 8, and $10 \mathrm{~g}$ of the adsorbent into different Erlenmeyer flask containing $200 \mathrm{~mL}$ of ALE. Each sample solution was shaken ranged from 1 to $3 \mathrm{~d}$, depending on time period of the isotherm equilibrium of $\mathrm{NH}_{4}{ }^{+}$. Then, the sample solutions were filtered using a $0.45 \mu \mathrm{m}$ membrane filter and the residual concentration of $\mathrm{NH}_{4}^{+}$was analysed using the HACH DR $5000 \mathrm{UV}-$ Vis Spectrophotometer. The Freundlich and Langmuir isotherm models were used to study the adsorption isotherm of $\mathrm{NH}_{4}{ }^{+}$from the ALE.

The general form of the Freundlich equation is $q_{\mathrm{e}}=K_{F} C^{1 / n}$ where $K_{\mathrm{F}}$ and $n$ are constants and $n>1$. The Freundlich isotherm can be linearised by transforming the equation into the linear form (equation 8) $[17,18]$ :

$$
\ln q_{\mathrm{e}}=\ln K_{\mathrm{F}}+\frac{1}{n} \ln C_{\mathrm{e}}
$$


where $q_{e}$ is the equilibrium amount of adsorbate adsorbed by per unit mass of adsorbent (in $\mathrm{mg} \mathrm{g}^{-1}$ ), $K_{\mathrm{F}}$ is the Freundlich constant (in $\mathrm{mg} \mathrm{g}^{-1}$ ), $n$ (dimensionless) is the heterogeneity factor which has a lower value for more heterogeneous surfaces, and $C_{\mathrm{e}}$ is the concentration of the adsorbate in the equilibrium solution (in $\mathrm{mg} \mathrm{L}^{-1}$ ).

The Langmuir isotherm is $q_{\mathrm{e}}=Q b C /(1+b C)$ where $b$ is a constant related to the energy of adsorption, and $Q$ is the ultimate adsorption capacity (maximum value of $q_{b}$ ). The linear form of the Langmuir isotherm can be written as equation $9[18,19]$ :

$$
\frac{1}{q_{e}}=\frac{1}{K_{\mathrm{L}} q_{\max } \mathrm{C}_{\mathrm{e}}}+\frac{1}{q_{\max }}
$$

where $q_{\mathrm{e}}$ is the equilibrium amount of adsorbate adsorbed by per unit mass of adsorbent (in $\mathrm{mg} \mathrm{g}^{-1}$ ), $C_{\mathrm{e}}$ is the concentration of the adsorbate in the equilibrium solution (in $\mathrm{mg} \mathrm{L}^{-1}$ ), $q_{\max }$ is the maximum adsorption capacity of the adsorbent (in $\mathrm{mg} \mathrm{g}^{-1}$ ) and $K_{\mathrm{L}}$ is the adsorption energy coefficient (in $\mathrm{L} \mathrm{mg}^{-1}$ ).

\section{Plug-flow column studies}

A schematic diagram for the laboratory scale plug-flow column is shown in Figure 1. The fixed-bed columns were made of acrylic tubes $2.1 \mathrm{~cm}$ internal diameter and $20 \mathrm{~cm}$ in height. The bed depths used in the experiments were 2 , 4, 6, 9, 12 and $15 \mathrm{~cm}$. In a typical experiment the known concentration of $\mathrm{NH}_{4}{ }^{+}$in ALE was pumped using a Masterflex peristaltic pump at a fixed flow rate $\left(\mathrm{Q}=0.11 \mathrm{~L} \mathrm{~h}^{-1}\right)$ to fill the packed-bed column heights. The concentration of $\mathrm{NH}_{4}^{+}$at inlet of the PFCR (storage tank), after passing the sand filter, and outlet of the PFCR treatment system were intermittently collected at defined time intervals and analysed based on Nesslerization method using HACH DR $5000 \mathrm{UV}-$ Vis spectrophotometer at the maximum wavelength of $425 \mathrm{~nm}$.

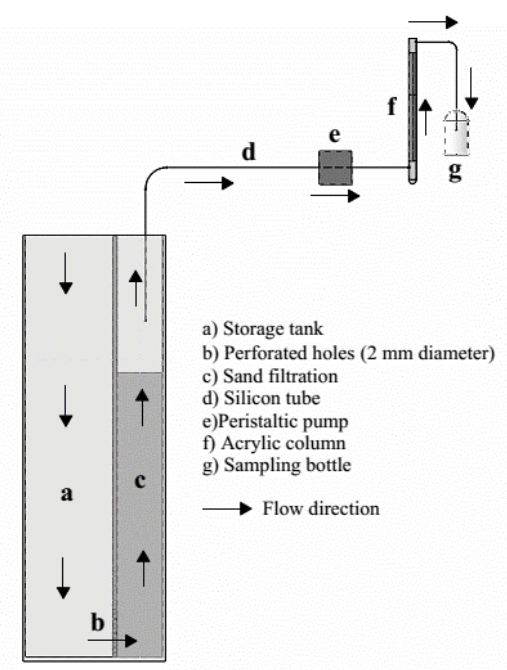

Figure 1. Experimental setup for plug-flow column operation

Data obtained from plug-flow column studies was analysed using the MTF models [11],[20] to understand the adsorption mechanisms of $\mathrm{NH}_{4}{ }^{+}$from aqueous solution onto GAC. The MTF models are expressed in equation 10:

$$
\ln \left(\frac{C_{o}}{C_{s}}\right)=\left[k_{L} a\right]_{g} \times e^{-\beta \times \ln (q)} \times t
$$

where $\mathrm{C}_{\mathrm{s}}$ is the concentration of the $\mathrm{NH}_{4}{ }^{+}$to depart from the column (in $\mathrm{mg} \mathrm{L}^{-1}$ ), $\mathrm{C}_{\mathrm{o}}$ is the concentration of the solute to enter into the column (in $\mathrm{mg} \mathrm{L}^{-1}$ ), $\left[k_{\mathrm{L}} a\right]_{\mathrm{g}}$ is the global mass transfer factor (in $\mathrm{h}^{-1}$ ), $\beta$ is the absorbent-adsorbent affinity parameter (in $\mathrm{g} \mathrm{h} \mathrm{mg}^{-1}$ ); $q$ is the cumulative quantity of the solute to adsorb onto GAC (in $\mathrm{mg} \mathrm{g}^{-1}$ ); and $t$ is the accumulation time (in $\mathrm{h}$ ). The mathematical deduction of the equation (10) can be simplified as equation 11: 


$$
\ln (q)=m \ln (t)+B
$$

where $m=1 / \beta$ and $B$ is the straight-line intercept of the plot $\ln (q)$ versus $\ln (t)$;

$$
B=\frac{\ln \left(\left[k_{\mathrm{L}} a\right]_{\mathrm{g}}\right)-\ln \left\{\ln \left(\frac{C_{\mathrm{o}}}{C_{\mathrm{S}}}\right)\right\}}{\beta}
$$

The value of $\left[k_{\mathrm{L}} a\right]_{\mathrm{g}}$ can be determined to use equation (12) since the index $B$ and parameter $\beta$ have been verified on a straight line. Using equation (13) permits to compute the values for $\left[k_{\mathrm{L}} a\right]_{\mathrm{f}}$, and equation (14) can be used to determine the $\left[k_{\mathrm{L}} a\right]_{\mathrm{d}}$.

$$
\begin{aligned}
& {\left[k_{\mathrm{L}} a\right]_{\mathrm{f}}=\left[k_{\mathrm{L}} a\right]_{\mathrm{g}} \times e^{-\beta \times \ln (q)}} \\
& {\left[k_{\mathrm{L}} a\right]_{\mathrm{d}}=\left[k_{\mathrm{L}} a\right]_{\mathrm{g}}-\left[k_{\mathrm{L}} a\right]_{\mathrm{f}}}
\end{aligned}
$$

where $\left[k_{\mathrm{L}} a\right]_{\mathrm{f}}$ is the film mass transfer factor $\left(\right.$ in $\left.\mathrm{h}^{-1}\right)$ and $\left[k_{\mathrm{L}} a\right]_{\mathrm{d}}$ is the porous diffusion $\left(\right.$ in $\left.^{-1}\right)$.

\section{Physical and chemical characteristics of the GAC}

\section{Results and Discussion}

The acidic and basic functional groups found on the surfaces of GAC were quantified using the Boehm's titration. It was found that a $1.35 \mathrm{mmol} \mathrm{g}^{-1}$ total acidic functional group consists of $0.63 \mathrm{mmol} \mathrm{g}$ ( $46 \%$ ) carboxylic, $0.44 \mathrm{mmol}$ $\mathrm{g}^{-1}(33 \%)$ lactonic and $0.28 \mathrm{mmol} \mathrm{g}{ }^{-1}(21 \%)$ phenolic group. A basic functional group $\left(0.85 \mathrm{mmol} \mathrm{g} \mathrm{g}^{-1}\right)$ of less than total acidic functional group $\left(1.35 \mathrm{mmol} \mathrm{g}^{-1}\right)$ was quantified for the GAC and could have more favourable to chemically attract more cations from a solution. The BET surface area of such GAC was measured using a Micromeritics Pulse Chemisorb 2705 apparatus to be $957 \mathrm{~m}^{2} \mathrm{~g}^{-1}$.

The surface morphology of GAC was investigated by SEM analysis and the SEM images are shown in Figure 2. Figure 2a shows that the SEM image of 500 times is wavy ripple morphology. Scanning the external surface of $\mathrm{GAC}$ with the high magnification images of 2,500 times (Figure 2b) and 5,000 times (Figure 2c) more specifically exhibit a rough surface with different sizes and shapes of the pores.
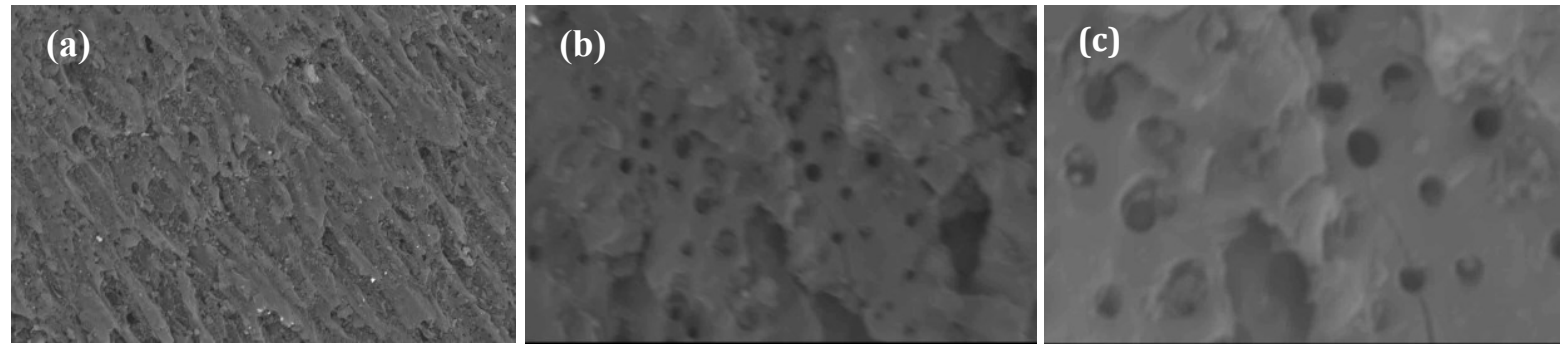

Figure 2. SEM photomicrograph of GAC: (a) overview 500 times magnification (b) 2,500 times magnification (c) overview 5,000 times magnification

The XRD analysis was performed to examine the mineralogy of the GAC sample, and the analysis result is depicted in Figure 3a. The XRD pattern of GAC has almost no diffraction lines; however, two broad peaks and one sharp peak have a diffraction maxima at diffraction angles $2 \theta$ of $23^{\circ}, 2 \theta$ of $43^{\circ}$ and $2 \theta$ of $81^{\circ}$, respectively. The peak $2 \theta$ of $23^{\circ}$ denotes strong small angle indicating an amophorous structure with high porosity, and both the peaks $2 \theta$ of $23^{\circ}$ and $2 \theta$ of $81^{\circ}$ represent the graphitic basal plane [21]. These peaks pattern similar with mineralogy of activated carbon cloth [21] and coconut shell-activated carbon [3]. A peak at $2 \theta$ of $43^{\circ}$ indicates the presence of minor phase of the quartz $\left(\mathrm{SiO}_{2}\right)$. 

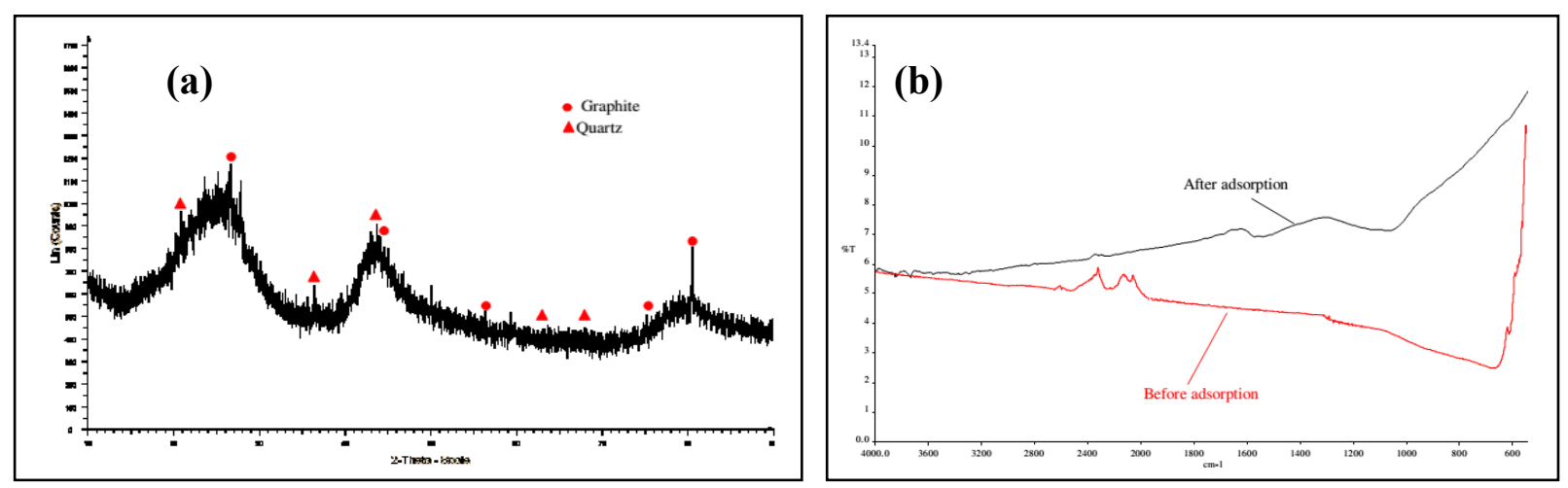

Figure 3. (a) XRD pattern of the GAC and (b)FTIR spectra of GAC of before and after $\mathrm{NH}_{4}{ }^{+}$adsorption

The FTIR spectra of GAC (Figure 3b) shows weak and broad band in the spectra with the range of $676-2,581 \mathrm{~cm}^{-1}$ before and with the range of $1,075-3,600 \mathrm{~cm}^{-1}$ after the adsorption of $\mathrm{NH}_{4}{ }^{+}$. The presence of spectra peaks at 2,341; 2,110; 1,320; and $676 \mathrm{~cm}^{-1}$ would be assigned as $\mathrm{C}=\mathrm{O}$ bonds; $\mathrm{C} \equiv \mathrm{C}$ bonds; $\mathrm{C}-\mathrm{O}$ stretch; and $\mathrm{C}-\mathrm{H}$ bending, respectively $[22,23]$. After the adsorption of $\mathrm{NH}_{4}{ }^{+}$, the FTIR spectra shows several new peaks within the range of $3,400-3,800 \mathrm{~cm}^{-1}$ to indicate the presence of $\mathrm{O}-\mathrm{H}$ groups [24]. The new broad band appear at 1,572 and $1,075 \mathrm{~cm}^{-1}$ could be assigned as hydrogen-bonded asymmetric carbonyl stretching and $\mathrm{C}-\mathrm{H}$ stretching, respectively, and would be caused by the adsorption of $\mathrm{NH}_{4}{ }^{+}$attached on the surface of GAC [3],[25].

\section{Adsorption kinetics of $\mathrm{NH}_{4}^{+}$onto the GAC}

In this study, the linearised forms of pseudo-first-order ( $\operatorname{see} \ln \left(q_{\mathrm{e}}-q_{\mathrm{t}}\right)$ versus $t$ in equation (3)) and pseudo-secondorder (see $t / q_{\mathrm{t}}$ versus $t$ in equation (6)) model were used to describe the adsorption kinetics of $\mathrm{NH}_{4}{ }^{+}$from ALE. The non-linear regression analysis was used in solving the equations (2) and (5) with supported by Microsoft Office Excel program due to linear regression of pseudo-first-order model often results in incorrect determination of its constants. The kinetic parameters $\left(k_{1}\right.$ and $\left.k_{2}\right)$ and theoretical equilibrium amount of $\mathrm{NH}_{4}{ }^{+}$adsorbed per unit mass of $\mathrm{GAC}, q_{\mathrm{e}}$ (theo), calculated by using these two linearised and non-linear models with their correlation coefficients are given in Table 2. The basis of selecting the best-fit kinetic model is that the value of $R^{2}$ is close to one and the value of $F_{\mathrm{e}}$ found should be lower. The experimental results of the adsorption kinetics data indicate that the pseudosecond-order kinetic model provides a best fit correlated value when compared with the pseudo-first-order kinetic model due to high $R^{2}$ and low $F_{\mathrm{e}}$ values were verified. As a conclusion, the adsorption phenomena could be leading to chemisorption rather than physisorption, suggesting that the chemisorption occurred to help the increased affinity of adsorbate-adsorbent could be caused by electron change and share between the $\mathrm{NH}_{4}{ }^{+}$ions and the acidic functional groups [22]. The value of $k_{2}$ is proportional to the amount of GAC (Table 2), because of the rate of $\mathrm{NH}_{4}^{+}$ adsorption can be increased by increasing the amount of GAC due to the availability of BET surface area and the number of active sites increase [26].

Table 2. Kinetic parameters obtained from the pseudo-first-order and pseudo second-order models for the adsorption of $\mathrm{NH}_{4}^{+}$onto GAC from ALE

\begin{tabular}{|c|c|c|c|c|c|c|c|c|c|}
\hline \multicolumn{10}{|c|}{ Linear regression } \\
\hline \multirow[b]{2}{*}{$\begin{array}{l}\text { Amount } \\
\text { (g) }\end{array}$} & \multicolumn{4}{|c|}{ Pseudo-first-order model } & \multicolumn{4}{|c|}{ Pseudo-second-order model } & \multirow[b]{2}{*}{$\begin{array}{l}q_{\mathrm{e}}(\exp ) \\
\left(\mathrm{mg} \mathrm{g}^{-1}\right)\end{array}$} \\
\hline & $\begin{array}{l}q_{\mathrm{e}}(\text { theo }) \\
\left(\mathrm{mg} \mathrm{g}^{-1}\right)\end{array}$ & $\begin{array}{c}k_{1} \\
\left(\min ^{-1}\right)\end{array}$ & $R^{2}$ & $F_{\mathrm{e}}$ & $\begin{array}{l}q_{\mathrm{e}}(\text { theo }) \\
\left(\mathrm{mg} \mathrm{g}^{-1}\right)\end{array}$ & $\begin{array}{c}k_{2} \\
\left(\mathrm{~g} \mathrm{mg}^{-1} \min ^{-1}\right)\end{array}$ & $R^{2}$ & $F_{\mathrm{e}}$ & \\
\hline 2 & 0.48 & 0.0001 & 0.901 & 0.441 & 0.94 & 0.0075 & 0.986 & 0.115 & 0.89 \\
\hline 6 & 0.32 & 0.0010 & 0.914 & 0.158 & 0.47 & 0.0101 & 0.979 & 0.048 & 0.46 \\
\hline 10 & 0.21 & 0.0009 & 0.916 & 0.125 & 0.33 & 0.0155 & 0.994 & 0.025 & 0.32 \\
\hline
\end{tabular}


Table 2 (cont'd). Kinetic parameters obtained from the pseudo-first-order and pseudo second-order models for the adsorption of $\mathrm{NH}_{4}^{+}$onto GAC from ALE

\begin{tabular}{|c|c|c|c|c|c|c|c|c|c|}
\hline \multirow[b]{3}{*}{$\begin{array}{l}\text { Amount } \\
\text { (g) }\end{array}$} & \multicolumn{8}{|c|}{ Non-linear regression } & \multirow[b]{3}{*}{$\begin{array}{l}q_{\mathrm{e}}(\exp ) \\
\left(\mathrm{mg} \mathrm{g}^{-1}\right)\end{array}$} \\
\hline & \multicolumn{4}{|c|}{ Pseudo-first-order model } & \multicolumn{4}{|c|}{ Pseudo-second-order model } & \\
\hline & $\begin{array}{l}q_{\mathrm{e}}(\text { theo }) \\
\left(\mathrm{mg} \mathrm{g}^{-1}\right)\end{array}$ & $\begin{array}{c}k_{1} \\
\left(\min ^{-1}\right)\end{array}$ & $R^{2}$ & $F_{\mathrm{e}}$ & $\begin{array}{l}q_{\mathrm{e}}(\text { theo }) \\
\left(\mathrm{mg} \mathrm{g}^{-1}\right)\end{array}$ & $\begin{array}{c}k_{2} \\
\left(\mathrm{~g} \mathrm{mg}^{-1} \min ^{-1}\right)\end{array}$ & $R^{2}$ & $F_{\mathrm{e}}$ & \\
\hline 2 & 0.83 & 0.0080 & 0.966 & 0.007 & 0.87 & 0.0119 & 0.973 & 0.005 & 0.89 \\
\hline 6 & 0.40 & 0.0056 & 0.974 & 0.0009 & 0.44 & 0.0152 & 0.978 & 0.0008 & 0.46 \\
\hline 10 & 0.29 & 0.0050 & 0.987 & 0.0002 & 0.32 & 0.0174 & 0.991 & 0.0001 & 0.32 \\
\hline
\end{tabular}

\section{Adsorption isotherms of $\mathrm{NH}_{4}^{+}$onto the GAC}

The curves obtained by plotting either $\ln \left(q_{\mathrm{e}}\right)$ versus $\ln \left(C_{\mathrm{e}}\right)$ in equation (8) or $1 / q_{\mathrm{e}}$ versus $1 / C_{\mathrm{e}}$ in equation (9) represent the Freundlich and Langmuir models; all the values for the parameters $n, K_{\mathrm{F}}, q_{\max }$ and $K_{\mathrm{L}}$ calculated using these two models are depicted in Table 3. This study found that the curves in Figure 4a can have to fit the experimental data for Freundlich adsorption isotherm comparing to Langmuir adsorption isotherm as represented by Figure $4 \mathrm{~b}$ due to the values of $R^{2}$ for the adsorption of $\mathrm{NH}_{4}^{+}$onto GAC from ALE are very close to one (Table 3). The surface of GAC covered by carboxylic, lactonic, phenolic and basic functional groups can allow the adsorption involved in the heterogeneous site progression with a multilayer mechanism of adsorption where the adsorbed $\mathrm{NH}_{4}{ }^{+}$ ions on the GAC surface can attract the $\mathrm{NH}_{4}{ }^{+}$ions from bulk water [27].

Table 3. The parameters $n, K_{\mathrm{F}}, q_{\max }$ and $K_{\mathrm{L}}$ for the adsorption of $\mathrm{NH}_{4}{ }^{+}$onto GAC from ALE

\begin{tabular}{lccccc}
\hline \multicolumn{2}{l}{ Freundlich Model } & \multicolumn{4}{c}{ Langmuir Model } \\
\hline $\boldsymbol{n}$ & $\begin{array}{c}\boldsymbol{K}_{\mathbf{F}} \\
\left(\mathbf{m g ~ g}^{-1}\right)\end{array}$ & $\boldsymbol{R}^{\mathbf{2}}$ & $\begin{array}{c}\boldsymbol{q}_{\text {max }} \\
\left(\mathbf{m g ~ g}^{-1}\right)\end{array}$ & $\left.\begin{array}{c}\boldsymbol{K}_{\mathrm{L}} \\
(\mathbf{L ~ m g}\end{array} \mathbf{~ g}^{-1}\right)$ & $\boldsymbol{R}^{\mathbf{2}}$ \\
\hline 0.485 & 0.003 & 0.990 & 0.40 & 0.007 & 0.961 \\
\hline
\end{tabular}
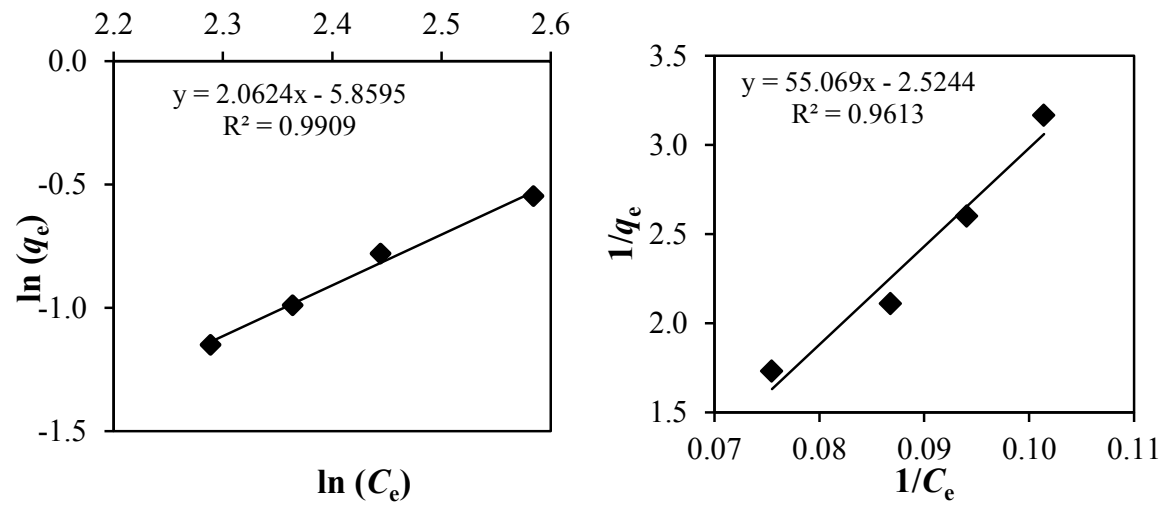

Figure 4. Linear line of plotting (a) $\ln \left(q_{\mathrm{e}}\right)$ versus $\ln \left(C_{\mathrm{e}}\right)$ and (b) $1 / q_{\mathrm{e}}$ versus $1 / C_{\mathrm{e}}$ for the adsorption of $\mathrm{NH}_{4}{ }^{+}$onto GAC from WTPE 


\section{Resistance of mass transfer factor}

A plot of $\ln (q)$ versus $\ln (t)$ in equation (11) gives us a straight line, intercept at $B$ and $\beta^{-1}$ is slope. The values for the parameters $B$ and $\beta$ for each curve are presented in Table 4. Correlation for all the parameters is very good $\left(R^{2}>\right.$ 0.97; see Table 4), meaning that both the index $B$ and parameter $\beta$ could be useful for scrutinising the mass transfer potential and the affinity of adsorbate-adsorbent for the adsorption of $\mathrm{NH}_{4}{ }^{+}$onto GAC from ALE. The experimental data validation (Table 4) shows that the value of $\beta$ decreases from 1.36 to 1.30 to 1.22 to 1.19 to 1.15 and to $1.14 \mathrm{~g}$ $\mathrm{h} \mathrm{mg}{ }^{-1}$ and the value of $B$ also decreases from -1.16 to -2.22 to -2.55 to -2.93 to -3.171 and to $-3.39 \mathrm{mg} \mathrm{g}^{-1}$ with increasing of the bed depth from 2 to 4 to 6 to 9 to 12 and to $15 \mathrm{~cm}$, respectively. The parameter of $\beta$ increased with increasing bed depth due to increases concentration of $\mathrm{NH}_{4}{ }^{+}$in bulk water compared in film zone in short bed depth can increase driving force for adsorption of $\mathrm{NH}_{4}{ }^{+}$that directly proportional with adsorbate-adsorbent affinity parameter.. The adsorption of $\mathrm{NH}_{4}{ }^{+}$onto GAC is easily affected by both van der Waals force and chemical interaction and could have a strong affinity of the absorbate-adsorbent [28],[29]. The decreases in $B$ value could be due to a high $\mathrm{NH}_{4}{ }^{+}$concentration in the stagnant film on the water side of the interface, affecting the value of driving force reduces because of the difference in $\mathrm{NH}_{4}{ }^{+}$concentration between the bulk water and film zone lowers.

Table 4. Results of determining the values of $\beta$ and $B$ for different GAC packed-bed column

\begin{tabular}{lccc}
\hline $\boldsymbol{h}(\mathbf{c m})$ & $\boldsymbol{\beta}\left(\mathbf{g ~ h ~ m g}^{\mathbf{- 1}}\right)$ & $\boldsymbol{B}\left(\mathbf{m g ~ g}^{-\mathbf{1}}\right)$ & $\boldsymbol{R}^{\mathbf{2}}$ \\
\hline 2 & 1.362 & -1.610 & 0.972 \\
4 & 1.295 & -2.224 & 0.981 \\
6 & 1.224 & -2.559 & 0.985 \\
9 & 1.186 & -2.931 & 0.985 \\
12 & 1.151 & -3.171 & 0.989 \\
15 & 1.145 & -3.394 & 0.987 \\
\hline
\end{tabular}

\section{Analysis of $\left[k_{\mathrm{L}} a\right]_{\mathrm{g}},\left[k_{\mathrm{L}} a\right]_{\mathrm{f}}$ and $\left[k_{\mathrm{L}} a\right]_{\mathrm{d}}$}

Using equation (11) permits us to determine the variations of $\left[k_{\mathrm{L}} a\right]_{\mathrm{g}}$ pursuant to the percentage of outflow if the parameters $B$ and $\beta$ were verified. The percentage of outflow is ratio of effluent and influent concentration multiply by 100 . Figure 5 a shows the variations of $\left[k_{\mathrm{L}} a\right]_{\mathrm{g}}$ decreased progressively from a high to low mass transfer potential with increasing of the percentage of outflow. The variation of $\left[k_{\mathrm{L}} a\right]_{\mathrm{g}}$ value for a $2 \mathrm{~cm}$ of the packed-bed column is quite high when comparing to other packed-bed columns of 4,6,9,12 and $15 \mathrm{~cm}$. This could be due to a high rate of water flow passing through a packed-bed column can cause a rapid movement of $\mathrm{NH}_{4}{ }^{+}$from the bulk water to acceptor sites at the surface of GAC.

Based on the curves in Figures $5 \mathrm{~b}$ and $5 \mathrm{c}$, the variations of $\left[k_{\mathrm{L}} a\right]_{\mathrm{f}}$ and $\left[k_{\mathrm{L}} a\right]_{\mathrm{d}}$ pursuant to the percentage of outflow can be used to determine the resistance of mass transfer for the adsorption of $\mathrm{NH}_{4}{ }^{+}$onto GAC from ALE, which would be dependent on either film mass transfer or porous diffusion. Evidence shows that the variations of $\left[k_{\mathrm{L}} a\right]_{\mathrm{f}}$ rapidly decrease, counterbalanced by the variations of $\left[k_{\mathrm{L}} a\right]_{\mathrm{d}}$ rapidly increase, when the percentages of outflow are still less than 26.2, 24.3, 16.5, 14.6, 9.5 and 7.7\% for the experimental runs with the packed-bed columns of 2, 4, 6, 9,12 , and $15 \mathrm{~cm}$, respectively. The trends of $\left[k_{\mathrm{L}} a\right]_{\mathrm{g}},\left[k_{\mathrm{L}} a\right]_{\mathrm{d}}$ and $\left[k_{\mathrm{L}} a\right]_{\mathrm{f}}$ pursuant percentage of outflow is slightly similar with that reported by Fulazzaky et.al [10]. They found that the resistance mass transfer factors rate in short packed-bed column is high due to fast flow condition, which is the driving force increasing and has a strong movement of $\mathrm{PO}_{4}{ }^{3-}$ molecules within bulk water toward the surface of granular laterites. As a conclusion, the application of the mass transfer factor models can determine that the resistance of mass transfer for the adsorption of $\mathrm{NH}_{4}{ }^{+}$onto GAC from ALE could be dependent on porous diffusion due to lower $\left[k_{\mathrm{L}} a\right]_{\mathrm{d}}$ value when percentage of outflow less than $30 \%$.

Even though the physical characteristic of the GAC has a porosity of $957 \mathrm{~m}^{2} \mathrm{~g}^{-1}$ of BET surface area, the movement of $\mathrm{NH}_{4}{ }^{+}$ions from the bulk water towards acceptor sites within the pores could be still difficult. This is suggested that the different accessibilities of the pore structure areas within the GAC cannot always be entered equally easily 
by all present inorganic and organic molecules in ALE [30]. The adsorption of $\mathrm{NH}_{4}{ }^{+}$from ALE onto GAC would be mainly affected by surface chemical nature rather than the van der Waals forces. Two possible mechanisms of the adsorption of $\mathrm{NH}_{4}{ }^{+}$onto GAC are suggested, such that: (1) the interaction between hydrogen of being composed of $\mathrm{NH}_{4}{ }^{+}$molecules and oxygen of being composed of carboxylic $(-\mathrm{COOH})$, lactonic $(\mathrm{C}=\mathrm{O})$ and phenolic $(-\mathrm{OH})$ groups as the main acidic acceptor sites at the surface of GAC [24] and (2) the electrostatic interaction between the positive charges of NH4+ ions and the negative charges of carboxylic, phenolic, hydroxyl surface functional groups [31]. It is suggested that the modifications of the adsorbent properties by both physical treatments to increase the BET surface area and chemical treatment to increase the number of active acceptor sites can be recommended to improve the ability of the GAC to remove $\mathrm{NH}_{4}{ }^{+}$from waters.
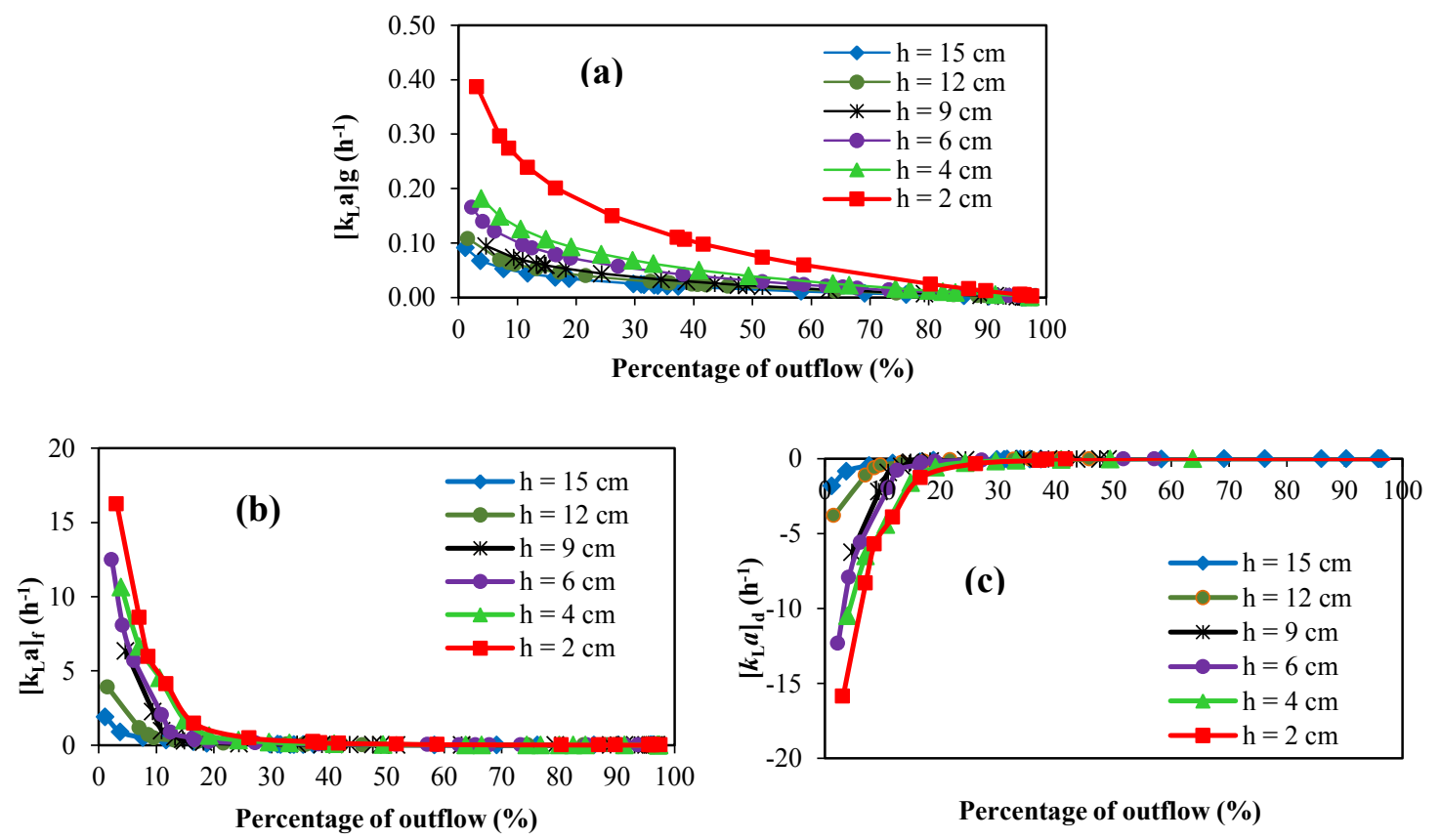

Figure 5. Variations of (a) $\left[k_{\mathrm{L}} a\right]_{\mathrm{g}}$, (b) $\left[k_{\mathrm{L}} a\right]_{\mathrm{d}}$ and (c) $\left[k_{\mathrm{L}} a\right]_{\mathrm{f}}$ pursuant to the percentage of outflow for six different depths of GAC packed-bed column

\section{Conclusion}

In this study, the verification of the isotherm and kinetic models has been performed to understand the behavior of the adsorption of $\mathrm{NH}_{4}{ }^{+}$from ALE onto GAC. The adsorption kinetic data were best described by pseudo-second order, suggesting that chemisorption would be involved during the adsorption process. The application of Freundlich models has best described the adsorption of $\mathrm{NH}_{4}{ }^{+}$onto GAC, suggesting that the adsorption of $\mathrm{NH}_{4}^{+}$ onto GAC would be occurred as multilayer. The variations of $\left[k_{\mathrm{L}} a\right]_{\mathrm{g}},\left[k_{\mathrm{L}} a\right]_{\mathrm{f}}$ and $\left[k_{\mathrm{L}} a\right]_{\mathrm{d}}$ versus percentage of outflow were found to be affected by bed depth of column and the resistance of mass transfer was dependent on porous diffusion. MTF models provide more information related to mechanism of mass transfer than the other models, which are more useful to understand the mechanisms of global, external and internal mass transfer for the adsorption of $\mathrm{NH}_{4}{ }^{+}$from ALE onto GAC and to facilitate the performance and effectiveness of plug-flow column in removing pollutants from waters.

\section{Acknowledgement}

The author thanks the Universiti Tun Hussien Onn Malaysia, for short term grant under grant no Vot U635. 


\section{References}

1. Fan, C., Glibert, P. M. and Burkholder, J. A. M. (2003). Characterization of the affinity for nitrogen, uptake kinetics, and environmental relationships for prorocentrum minimum in natural blooms and laboratory cultures. Harmful Algae, 2(4): 283-299.

2. Halim, A. A., Aziz, H. A., Johari, M. A. M. and Ariffin, K. S. (2010). Comparison study of ammonia and COD adsorption on zeolite, activated carbon and composite materials in landfill leachate treatment. Desalination, 262(1-3): 31-35.

3. Boopathy, R., Karthikeyan, S., Mandal, A. B. and Sekaran, G. (2013). Adsorption of ammonium ion by coconut shell-activated carbon from aqueous solution: Kinetic, isotherm, and thermodynamic studies. Environmental Science and Pollution Research International, 20(1): 533-542.

4. Gan, L., Zuo, J., Xie, B., Li, P. and Huang, X. (2012). Zeolite (Na) modified by nano-Fe particles adsorbing phosphate in rainwater runoff. Journal of Environmental Sciences, 24(11): 1929-1933.

5. Han, R., Zou, L., Zhao, X., Xu, Y., Xu, F., Li, Y. and Wang, Y. (2009). Characterization and properties of iron oxide-coated zeolite as adsorbent for removal of copper(II) from solution in fixed bed column. Chemical Engineering Journal, 149(1-3): 123-131.

6. Ruhl, A. S., Zietzschmann, F., Altmann, J., Meinel, F., Sperlich, A. and Jekel, M. (2015). Stratification of granular activated carbon filters for advanced wastewater treatment. Water, Air, and Soil Pollution, 226(11): 384-394.

7. Zayadi, N., Othman, N. and Hamdan, R. (2016). A potential waste to be selected as media for metal and nutrient removal. IOP Conference Series: Materials Science and Engineering, 136: 1-8.

8. Vassileva, P., Tzvetkova, P. and Nickolov, R. (2009). Removal of ammonium ions from aqueous solutions with coal-based activated carbons modified by oxidation. Fuel, 88(2): 387-390.

9. Halim, A. A., Aziz, H. A., Johari, M. A. M., Ariffin, K. S. and Adlan, M. N. (2010). Ammoniacal nitrogen and COD removal from semi-aerobic landfill leachate using a composite adsorbent: fixed bed column adsorption performance. Journal of Hazardous Materials, 175(1-3): 960-964.

10. Fulazzaky, M. A., Khamidun, M. H., Din, M. F. M. and Yusoff, A. R. M. (2014). Adsorption of phosphate from domestic wastewater treatment plant effluent onto the laterites in a hydrodynamic column. Chemical Engineering Journal, 258: 10-17.

11. Fulazzaky, M. A., Khamidun, M. H. and Omar, R. (2013). Understanding of mass transfer resistance for the adsorption of solute onto porous material from the modified mass transfer factor models. Chemical Engineering Journal, 228: 1023-1029.

12. Tazibet, S., Boucheffa, Y., Lodewyckx, P., Velasco, L. F. and Boutillara, Y. (2016). Microporous and mesoporous materials evidence for the effect of the cooling down step on activated carbon adsorption properties. Microporous and Mesoporous Materials, 221: 67-75.

13. Langmuir, I. (1916). The constitution and fundamental properties of solids and liquids. Journal of the American Chemical Society, 38 (11): 2221-2295.

14. Ho, Y. S. and Mckay, G. (1998). A comparison of chemisorption kinetic models applied to pollutant removal on various sorbents. Trans IChemE, 76: 332-340.

15. Ho, Y. S. (2006). Review of second-order models for adsorption systems. Journal of Hazardous Materials, 136(3): 681-689.

16. Ribas, M. C., Adebayo, M. A., Prola, L. D. T., Lima, E. C., Cataluña, R., Feris, L. A., and Calvete, T. (2014). Comparison of a homemade cocoa shell activated carbon with commercial activated carbon for the removal of reactive violet 5 dye from aqueous solutions. Chemical Engineering Journal, 248: 315-326.

17. Siu, P. C. C., Koong, L. F., Saleem, J., Barford, J. and McKay, G. (2015). Equilibrium and kinetics of copper ions removal from wastewater by ion exchange. Chinese Journal of Chemical Engineering, 24(1): 94-100.

18. Freundlich, H. M. F. (1906). Over the adsorption in solution. The Journal of Physical Chemistry, 57: 385-470.

19. Chan, L. S., Cheung, W. H., Allen, S. J. and McKay, G. (2012). Error analysis of adsorption isotherm models for acid dyes onto bamboo derived activated carbon. Chinese Journal of Chemical Engineering, 20 (3): 535542.

20. Fulazzaky, M. A. (2011). Determining the resistance of mass transfer for adsorption of the surfactants onto granular activated carbons from hydrodynamic column. Chemical Engineering Journal, 166(3): 832-840.

21. Dhawan, R. and Meenakshi, K. K. B. (2015). Isotherms, kinetics and thermodynamics for adsorption of pyridine vapors on modified activated carbons. Adsorption, 21:37-52. 
22. Şencan, A., Karaboyaci, M. and Kiliç, M. (2015). Determination of lead(II) sorption capacity of hazelnut shell and activated carbon obtained from hazelnut shell activated with $\mathrm{ZnCl}_{2}$. Environmental Science and Pollution Research, 22: 3238-3248.

23. Saha, P. Das, Chakraborty, S. and Chowdhury, S. (2012). Batch and continuous (fixed-bed column) biosorption of crystal violet by Artocarpus heterophyllus (jackfruit) leaf powder. Colloids and Surfaces. B, Biointerfaces, 92: $262-70$.

24. Bandosz, T. J. and Petit, C. (2009). The reactive adsorption of ammonia on activated carbons modified by impregnation with inorganic compounds. Journal of Colloid and Interface Science, 338(2): 329-345.

25. Salman, J. M. (2014). Optimization of preparation conditions for activated carbon from palm oil fronds using response surface methodology on removal of pesticides from aqueous solution. Arabian Journal of Chemistry, 7(1): 101-108.

26. Chand, P. and Pakade, Y. B. (2015). Synthesis and characterization of hydroxyapatite nanoparticles impregnated on apple pomace to enhanced adsorption of $\mathrm{Pb}(\mathrm{II}), \mathrm{Cd}(\mathrm{II})$, and $\mathrm{Ni}(\mathrm{II})$ ions from aqueous solution. Environmental Science and Pollution Research, 22(14): 10919-10929.

27. Arshadi, M., Salimivahid, F., Salvacion, J. W. L. and Soleymanzadeh, M. (2014). Adsorption studies of methyl orange on an immobilized mn-nanoparticle: kinetic and thermodynamic. RSC Advances, 4: 16005-16017.

28. Fulazzaky, M. A. (2013). Calculation of the release of total organic matter and total mineral using the hydrodynamic equations applied to palm oil mill effluent treatment by cascaded anaerobic ponds. Bioprocess and Biosystems Engineering, 36(1): 11-21.

29. Khamidun, M. H., Fulazzaky, M. A., Md Din, M. F. and Mohd Yusoff, A. R. (2014). Resistance of mass transfer, kinetic and isotherm study of ammonium removal by using a hybrid plug-flow column reactor (HPFCR). In W. P. Sung, Jimmy C. M. Kao, and Ran Chen (Eds.), Proceedings of the 2013 International Conference on Frontier of Energy and Environment Engineering, ICFEEE 2013. Taylor \& Francis Group, Xiam: pp. 555-559.

30. Zietzschmann, F., Worch, E., Altmann, J., Ruhl, A. S., Sperlich, A., Meinel, F. and Jekel, M. (2014). Impact of EfOM size on competition in activated carbon adsorption of organic micro-pollutants from treated wastewater. Water Research, 65: 297-306.

31. Foo, K. Y., Lee, L. K. and Hameed, B. H. (2013). Batch adsorption of semi-aerobic landfill leachate by granular activated carbon prepared by microwave heating. Chemical Engineering Journal, 222: 259-264. 